\title{
Prepoznava in ukrepanje ob samomorilnem vedenju
}

\section{Vita Poštuvan}

Univerza na Primorskem

vita.postuvan@upr.si

\section{Saška Roškar}

Nacionalni inštitut za javno zdravje

saska.roskar@nijz.si

\section{Alenka Tančič Grum \\ Nacionalni inštitut za javno zdravje \\ alenka.tancic-grum@nijz.si}

Samomor je velik družbeni in javnozdravstveni problem. Eden izmed ključnih načinov preprečevanja samomora je izobraževanje in sodelovanje $z$ vratarji sistema (angl. gatekeepers), med katere se uvrščajo tudi psihologi. Pomembno je, da imajo vratarji sistema občutek kompetentnosti in potrebna znanja za ukrepanje v primeru samomorilnega vedenja. Med najpomembnejše kompetence, ki so za psihologe na različnih delovnih mestih pomembne za ukrepanje ob samomorilni ogroženosti, se uvrščajo: prepoznavanje samomorilnega vedenja, ustrezno spraševanje o samomorilnih težnjah, presoja o resnosti ogroženosti, ukrepanje ob resni ogroženosti in nudenje (osnovne) strokovne pomoči. Pomembno je, da se psihologi kot eni izmed bolj izpostavljenih vratarjev sistema informirajo o znakih samomorilnega vedenja, kar omogoča pravočasno identifikacijo ogroženih. V fazi intervencije, torej ukrepanja v primeru samomorilne ogroženosti, je pomembno, da razumejo in sprejemajo meje osebne odgovornosti in da se tega občutka ne prestrašijo, saj to lahko zaviralno vpliva na ukrepanje v primeru samomorilnega vedenja. Poznavanje in razumevanje pristopa Vprašaj - prepričaj - napoti pomaga strukturirati ukrepanje v primeru samomorilne stiske, tudi v zvezi z napotovanjem naprej oz. vključevanjem drugih strokovnjakov. Pomembno je, da imajo psihologi vpogled tudi v značilnosti žalovanja po samomoru, vključno z nudenjem primerne opore žalujočim. Pri tem je lahko v pomoč Model rastoče rože, ki prikaže pomen socialnega okolja za razumevanje doživljanja ob smrti, predvsem ob samomoru (integracija dogodka, ritualov, izražanja svojih čustev $\mathrm{z}$ odzivi družine, okolice in sistemov).

\section{Izhodišča}

V različnih študijah so ugotavljali, da lahko edukacija strokovnjakov iz vsebin duševnega zdravja in samomorilnosti pomembno prispeva $\mathrm{k}$ pra- 
vočasni prepoznavi in obravnavi duševne stiske, vključno s samomorilno ogroženostjo (Rutz idr., 1992; Roškar idr., 2010; Hegerl idr., 2009). Različni vratarji sistema (zdravniki družinske medicine, medicinske sestre, policisti, socialni delavci), ki prihajajo $\mathrm{v}$ stik $\mathrm{z}$ ranljivimi posamezniki, poročajo o težavah s prepoznavanjem duševnih stisk in samomorilnosti ter o pomanjkanju veščin dela $\mathrm{z}$ ranljivimi posamezniki. Za optimalen učinek na področju preprečevanja samomora sta zato potrebna dosledno in kontinuirano sodelovanje $\mathrm{z}$ vsemi omenjenimi in njihovo izobraževanje (Mann idr., 2005).

Psiholog je zagotovo eden izmed vratarjev sistema, ki je pri preprečevanju samomora nepogrešljiv. Ne glede na delovno okolje (v javnem ali zasebnem sektorju) se psiholog pri svojem delu namreč pogosto srečuje s področjem osebnih stisk in tako tudi s samomorilnostjo ter $\mathrm{z}$ vsemi vidiki preprečevanja tega pojava (od prepoznave različno ogroženih posameznikov, intervencij, ki vključujejo napotitev k specializiranim strokovnjakom, vse do postvencije, ki se usmerja v delo z žalujočimi). Boljše poznavanje in razumevanje zakonitosti pojava samomorilnosti prispeva tudi $k$ večji učinkovitosti pri njegovem preprečevanju.

\section{Različne oblike samomorilnosti}

Samomorilnost obsega vrsto različnih, bolj in manj resnih pojavnih oblik, katerih skupni imenovalec je želja po škodovanju samemu sebi z namenom povzročitve smrti. Stopnjevanje od blažjih do resnejših oblik samomorilnosti imenujemo samomorilni proces. Slednji se nanaša na vse oblike samomorilnosti, ki se lahko razvijejo in stopnjujejo od samomorilnih misli in namena (pri katerih je poudarjena kognitivna (in čustvena) komponenta) do oblik, v katere je vključena tudi vedenjska komponenta (poskusi samomora ter samomor) (Neeleman idr., 2004). Samomorilne misli ali samomorilne ideacije se lahko pojavljajo v pasivni (npr. oseba si želi, da bi se ji nekaj zgodilo ali da bi umrla) ali aktivni obliki (oseba razmišlja o tem, da bi sama končala svoje življenje). Misli o samomoru so lahko prehodne in splošne, lahko pa so dolgotrajnejše, bolj razdelane in podrobnejše (npr. vključujejo že izbrano metodo), pri čemer govorimo že o samomorilnem namenu in celo načrtu (O'Carroll idr., 1996; van Heeringen, 2001). Razmišljanje o smrti (in tudi o samomoru) je eno od bazičnih eksistencialnih vprašanj (zato tudi zadeva vsakogar od nas), take misli pa postanejo nevarne, ko posameznik $\mathrm{v}$ njih vidi rešitev svoje stiske. $\mathrm{V}$ takih primerih samomorilne misli pogosto predstavljajo začetno fazo razvoja samomorilnega vedenja, ki se stopnjuje do resnejših oblik (npr. poskus samomora). Prej ko v razvoju 
samomorilnega procesa posameznika identificiramo, večje so možnosti, da bomo pri preventivi uspešni.

Retterstol (1993) navaja, da je pomemben mejnik v razvoju (in prepoznavi) samomorilnosti prag, ki samomorilni proces razdeli na dva dela. Oblike samomorilnosti, ki se nahajajo pod tem pragom (samomorilne misli, samomorilni namen in načrt), niso opazne drugim. Te oblike samomorilnega vedenja včasih niso opazne niti samomorilnemu posamezniku oz. jih le-ta ne prepozna. Posameznik prestopi prag, se razkrije (ang. selfdisclosure), ko preko oblik samomorilnega vedênja, ki jih okolica lahko opazi, vstopi v »komunikacijo« $\mathrm{z}$ okoljem. O svojih samomorilnih namenih lahko posameznik komunicira $\mathrm{z}$ okoljem preko neverbalnih ali verbalnih znakov. V skupino neverbalnih znakov spadajo npr. poslovilno pismo, umikanje v samoto, razdajanje svojega imetja, pisanje oporoke, ko za to ni objektivnega razloga (npr. ni prisotna bolezen ali starost, ko je smrt pričakovana), poslavljanje od bližnjih itd. V skupino verbalnih znakov pa sodi bolj ali manj jasno izražanje samomorilnih namenov. Izjave, ob katerih moramo postati pozorni, so npr.: "Ne morem več«, "Najraje bi se za vedno umaknil«, »Najraje bi za vedno zaspal« itd.

\section{Načini preventive samomorilnega vedenja}

Oblike preprečevanja samomorilnega vedenja so različne in odvisne od tega, v kateri fazi samomorilnega procesa izvajamo naše aktivnosti. Slednje tudi pomeni, da so strategije preprečevanja samomora lahko usmerjene $\mathrm{v}$ večje število oseb $\mathrm{z}$ manjšim tveganjem ali manjše število oseb $\mathrm{z}$ večjim tveganjem za razvoj tega vedenja (Mann idr., 2005; Zalsman idr., 2016).

\section{Strategije za večje število oseb z manjšim tveganjem}

Strategije v tej skupini so univerzalnejše in $\mathrm{z}$ njimi nagovarjamo vse ljudi, ne glede na njihovo stopnjo ogroženosti. To pomeni, da bodo te strategije koristne za celotno populacijo, v kateri so posamezniki, ki ne izkazujejo nobenega tveganja, kot tudi posamezniki $z$ manjšim in večjim tveganjem za razvoj samomorilnega vedenja. Med te strategije spadajo:

- promocija duševnega zdravja;

- politika na področju duševnega zdravja;

- zmanjševanje porabe alkohola;

- povečevanje dostopnosti do strokovne pomoči;

- omejevanje dostopnosti do sredstev za samomor;

- odgovorno medijsko poročanje o samomoru; 
- ozaveščanje o pomenu duševnega zdravja, duševnih bolezni in iskanja pomoči;

- zmanjševanje stigme na področju duševnih težav.

Strategije za manjše število oseb z večjim tveganjem

Strategije v tej skupini so specifičnejše in z njimi nagovarjamo tisti del populacije, ki je bolj ogrožen. Lahko so usmerjene v skupine ljudi ali individualno, v ogrožene posameznike.

Med te strategije spadajo:

- informiranje in sodelovanje $\mathrm{z}$ vsemi vratarji sistema, ki prihajajo $\mathrm{v}$ stik z ogroženimi (edukacija o znakih samomorilnega vedenja, ukrepanje v primeru samomorilne ogroženosti ...);

- različne intervencije za ranljive skupine;

- telefoni za pomoč v stiski;

- identifikacija, intervencija in spremljanje ogroženih;

- zdravljenje in spremljanje ogroženih.

Psihologi pri svojem delu prijahamo v stik z osebami, ki so na različnih stopnjah samomorilnega procesa, zato je pomembno, da imamo o tem pojavu široko znanje. Skladno s tem se kompetence psihologa za delo na področju preprečevanja samomora raztezajo od splošnejših do precej specifičnih.

\section{Kompetence za prepoznavo in ukrepanje ob samomorilnem vedenju}

Znanja in kompetence, ki so za psihologa pomembne na področju preprečevanja samomora, so prikazane v preglednici 1.

Poskusite uriti kompetence na naslednjih področjih preko primerov nalog, vaj oz. aktivnosti. Reflektiranje svojih izkušenj in priprava na kritične situacije psihologu in drugim vratarjem sistema lahko pomagata $\mathrm{k}$ boljšemu strokovnemu ravnanju. Spodnje aktivnosti lahko pomagajo razvijati opisane kompetence in znanja.

\section{Poznavanje načinov promocije duševnega zdravja in preventive duševnih motenj}

V službi vas zadolžijo, da napišete prispevek o duševnem zdravju, ki se nanaša na vaše relevantno področje dela. Razmislite o naslednjih vidikih prispevka: 
Preglednica 1 Znanja in kompetence psihologov na področju preprečevanja samomora

\begin{tabular}{|c|c|}
\hline Znanja & Kompetence \\
\hline $\begin{array}{l}\text { - Značilnosti pojava samomorilnega vede- } \\
\text { nja v slovenskem prostoru } \\
\text { - Dejavniki tveganja in varovalni dejavniki } \\
\text { za razvoj samomorilnega vedenja } \\
\text { - Razvoj samomorilnega vedenja (blažje in } \\
\text { resne oblike) } \\
\text { - Opozorilni znaki samomorilnega vedenja } \\
\text { - Ukrepanje pri različnih oblikah samomo- } \\
\text { rilnega vedenja } \\
\text { - Poznavanje značilnosti depresije kot naj- } \\
\text { pomembnejšega dejavnika tveganja } \\
\text { - Opredelitev preventivnih aktivnosti in } \\
\text { njihova aplikacija v praksi }\end{array}$ & $\begin{array}{l}\text { - Poznavanje načinov promocije duševnega } \\
\text { zdravja } \\
\text { - Prepoznava znakov samomorilnega vede- } \\
\text { nja in dejavnikov tveganja } \\
\text { - Poznavanje učinkovitih preventivnih } \\
\text { ukrepov za preprečevanje samomora } \\
\text { - Spretnosti interveniranja pri akutni sa- } \\
\text { momorilni stiski posameznika } \\
\text { - Spretnosti nudenja podpore v primeru } \\
\text { smrti bližnjega zaradi samomora } \\
\text { - Poznavanje virov pomoči in možnosti } \\
\text { obravnave ter primerne napotitve }\end{array}$ \\
\hline
\end{tabular}

- Kaj bi želeli sporočiti s prispevkom? Bi naslavljali širše, univerzalnejše teme in težave na področju duševnega zdravja ali bi se osredotočili na specifičnejše vsebine?

- Katero skupino bi naslovili? So to neposredni udeleženci vaših storitev, njihovi svojci, bližnji ali morda strokovnjaki, ki delajo z njimi? Bi naslovili širšo javnost?

- Razmislite, kako drugače je, če prispevek usmerite v ozko področje posameznih psiholoških intervencij, v primerjavi s pisanjem za splošno javnost in za vidik javnega duševnega zdravja.

- Katere načine krepitve duševnega zdravja bi izpostavili za vašo ciljno publiko?

Če imate možnost, izvedite to nalogo s kolegom, ki dela na podobnem področju dela kot vi, vendar je njegova ciljna publika drugačna. Skupaj premislita:

- V čem so vajine intervencije oz. zapisi podobni oz. različni?

- Kako bi lahko izkušnje $\mathrm{z}$ obeh vidikov povezali med seboj v univerzalnejšo preventivo?

- Je kak vidik, ki ste ga pri pisanju spregledali?

Namen naloge je ozavestiti različne načine preventive duševnih težav (vključno s samomorilnim vedenjem) in promocije duševnega zdravja. Nekateri pristopi na univerzalni ravni preventive se med seboj zelo povezujejo oz. so si podobni. To je pričakovano, saj je njihov namen naslavljati najširšo družbo. Specifičnejše intervencije so med seboj bolj različnejše. 


\section{Prepoznava znakov samomorilnega vedenja}

Predstavljajte si, da se boste srečali s spodaj navedenimi osebami (lahko v okviru svojega dela ali pa v svojem prostem času). O osebah pred srečanjem veste samo toliko, kot je zapisano spodaj (iz predhodnega telefonskega pogovora ali informacij, ki so vam jih podali drugi).

Lukaje dijakv 2. letniku gimnazije, kamor se vsak dan vozi iz podeželskega naselja. Med sošolci nima pravega prijatelja in se pogosto počuti osamljenega, še posebej, ker sta se ne dolgo nazaj razšla s punco. Rad igra kitaro, a zanjo ni veliko časa, saj doma pričakujejo veliko pomoči na manjši kmetiji. $V$ šoli mu gre v redu, težave ima le pri matematiki. Včasih se mu zdi vse brez veze in se poigrava z mislijo, kako bi bilo, če ga ne bi bilo.

Marjeta je knjižničarka srednjih let. Že več kot dva meseca se počuti zelo na tleh. Začelo se je z ločitvenim postopkom in konflikti z domačimi. Pogosto je razdražljiva, se včasih zjoka brez razloga in nima veselja do druženja z ljudmi. Slabo spi, pogosto jo boli trebuh. Čeprav je včasih rada kuhala, ji to zdaj predstavlja napor.

Tone je upokojenec že 15 let in živi sam v manjšem stanovanju. Hčerka je odrasla in živi $v$ tujini, približno enkrat na mesec se slišita po telefonu. Ima težave $z$ nespečnostjo, bolečinami v hrbtu in s koncentracijo. Pred pol leta mu je zdravnik diagnosticiral začetek Alzheimerjeve bolezni. Boji se prihodnosti in odvisnosti od drugih. Čedalje pogosteje se srečuje s samomorilnimi mislimi.

Za pogovor z vsako posamezno osebo razmislite:

- Na kakšen način boste začeli pogovor?

- Ali boste preverili depresivno/samomorilno ogroženost? In če, na kakšen način, kakšna vprašanja boste uporabili?

- Kaj bi storili v primeru zaznane samomorilne ogroženosti?

- Kam bi usmerili/napotili osebo po nadaljnjo pomoč? S kom bi se sami posvetovali?

- Kako bi se vaša obravnava razlikovala, če bi osebo poznali iz vašega osebnega življenja?

- S kakšnimi ovirami bi se lahko srečali pri takšnem pogovoru? Česa bi se bali?

- Kaj/kdo bi vam bil(o) v oporo $v$ takšnem pogovoru in po njem? 
Zgoraj navedeni podatki pri vseh treh osebah nakazujejo depresivno/samomorilno ogroženost. Zato je bistveno, da preverimo, ali so te osebe dejansko ogrožene. Pri preverjanju depresivne simptomatike si lahko pomagamo s kakšnim od presejalnih vprašalnikov (za izhodišče vprašanj), npr. P H Q-9 ali Zungovo lestvico depresivnosti, ali z dobrim poznavanjem simptomov, diagnostičnih kriterijev. O samomorilni ogroženosti lahko vprašamo na različne načine, lahko uporabimo neposreden način (»Ali razmišljate o samomoru?«) ali pa prehajamo od splošnejših vprašanj (o počutju) k neposrednejšim (»Ali ste kdaj pomislili na smrt?«). Način bo torej prilagojen nam in sogovorniku, bistveno pa je, da v pogovoru izvemo, ali posameznik razmišlja o samomoru in kako ogrožen je (na kateri stopnji se nahaja). Pri spraševanju nam je lahko v pomoč pristop Vprašaj - prepričaj - napoti (glej https://www.qprinstitute.com). Pri pogovoru s posameznikom, ki razmišlja o samomoru, je pomembno predvsem empatično poslušanje. Posameznika ne prekinjajmo, ne minimalizirajmo njegove stiske, ampak mu prisluhnimo in mu dajmo prostor, da spregovori o svoji stiski.

Če se v pogovoru izkaže, da je posameznik resno samomorilno ogrožen, je pomembno, da poznamo ustrezne ukrepe (v okviru delovne organizacije in izven nje). To pomeni tudi, da v primeru resne ogroženosti vztrajamo, da gre posameznik po strokovno pomoč (zdravnik, bolnišnica ...) in da mu zagotovimo spremstvo. Iz njegove bližine odstranimo vsa nevarna sredstva, npr. zdravila, ostre predmete, orožje, vrvi, ki bi jih posameznik lahko uporabil pri samomoru, s posameznikom pa lahko sklenemo tudi zavezo za življenje. Dobro je tudi, da smo seznanjeni z viri pomoči, ki so na voljo v našem (lokalnem) okolju in kamor lahko posameznika usmerimo. Spodaj navajamo nekaj splošnih virov pomoči.

Ne smemo pa pozabiti tudi nase in na svojo vlogo $\mathrm{v}$ taki situaciji. Zavedati se moramo lastnih stališč in prepričanj o pojavu samomorilnosti, čustev in omejitev, s katerimi se lahko ob tem srečamo, in drugih vplivov/posledic, ki jih ima lahko tak pogovor za nas. Pomembno je, da imamo tudi mi zgrajeno mrežo podpore in da vemo, kam/na koga se lahko obrnemo v primeru lastne stiske.

\section{Spretnosti nudenja podpore $v$ primeru smrti bližnjega zaradi samomora}

Predstavljajte si naslednjo situacijo in poskusite razmisliti, kako bi reagirali. Pomagajte si z izhodišči v diskusiji.

Vaš/-a klient/-ka se naroči na srečanje z vami. Sporoči vam, da je sreča- 
nje nujno, ker je pred kratkim izvedel/-a za novico, da je nekdo od njegovih/njenih bližnjih umrl zaradi samomora. Kvam prihaja na razgovor, saj sam/-a ne razume situacije, je pretresen/-a in poln/-a različnih čustev.

Namesto klienta/-ke si lahko predstavljate tudi srečanje s sodelavcem ali $\mathrm{z}$ drugimi relevantnimi osebami, s katerimi se srečujete pri delu.

Razmislite:

- Kako se počutite pred pogovorom s klientom/-ko? Katera čustva prevladujejo pri vas?

- Katere informacije predvidevate, da bodo klienta/-ko zanimale? Katere informacije pred srečanjem potrebujete vi?

- V katero smer boste usmerjali pogovor? Kako boste pridobili informacije o okoliščinah samomora? Na kak način boste spodbudili, da oseba izrazi svoja čustva? Kako je možno spremeniti pozornost na vedenja, s katerimi osebo vrnete $\mathrm{v}$ sedanjo situacijo?

- Kam boste osebo usmerili po nadaljnjo pomoč?

- Kako boste po pogovoru poskrbeli zase? Katere informacije boste želeli imeti po srečanju?

Težko je napovedati, kako bo potekal pogovor z nekom, ki je ravno izgubil bližnjega zaradi samomora. Ljudje pogosto iščejo informacije, ki bi jim lahko pojasnile okoliščine dogodka. Bližnjim je potrebno pojasniti kompleksnost samomorilnega vedenja. Prav tako je dobro, da psiholog v taki situaciji omogoči neobsojajoče izražanje čustev: žalosti, jeze, obupa, sramu, osamljenosti, pa tudi olajšanja, hvaležnosti in doživljanja milosti do preminule osebe. Po napornem čustvenem delu je dobro usmeriti pozornost $v$ sedanjost, npr. v aktivnosti, ki jih oseba načrtuje še ta dan, teden, in spodbuditi take, ki omogočajo skrb zase. Ob takšni novici so ljudje v šoku in $\mathrm{v}$ prvi fazi žalovanja. V drugi fazi gredo skozi boleče obdobje, ki se zaključi s fazo vračanja v vsakodnevno življenje. Ob tem nekateri doživijo tudi posttravmatsko rast.

Psiholog si lahko v situacijah, kjer mora nuditi takšno podporo, pomaga s pristopi prve psihološke pomoči ( $\mathrm{ki}$ jim $\mathrm{v}$ tej knjigi namenjamo posebno poglavje v tej knjigi). Hkrati je potrebno krepiti kompetence ocenjevanja in interveniranja, saj mora imeti psiholog v situacijah dovolj fleksibilnosti, da svoje delo prilagodi glede na posamezno situacijo. Psiholog mora reflektirati tudi svoje odzive na ravni doživljanja in reagiranja, da ima dovolj notranje moči za takšne intervencije. 


\section{Viri pomoči v pomoč pri ukrepanju ob samomorilnem vedenju}

Podpora osebi v samomorilni stiski se najučinkoviteje izvaja v sodelovanju z različnimi vključenimi osebami, institucijami. Zato je ključno, da poznamo vire pomoči, ki so pri nas že na voljo. Prvi vir strokovne pomoči je izbrani osebni zdravnik. Kadar je stiska zelo huda in osebni zdravnik ni dosegljiv, se posameznik lahko obrne neposredno na:

- dežurnega zdravnika,

- dežurno ambulanto najbližje psihiatrične bolnišnice,

- reševalno službo (112) ali

- urgentno psihiatrično ambulanto $\mathrm{v}$ Centru za izvenbolnišnično psihiatrijo v Ljubljani (o1 4750 670).

V zdravstvenih domovih so na voljo tudi psihoedukativne delavnice Podpora pri spoprijemanju $\mathrm{z}$ depresijo, Podpora pri spoprijemanju s tesnobo, Spoprijemanje s stresom in kratka delavnica Tehnike sproščanja. Udeležbo na delavnicah krije Zavod za zdravstveno zavarovanje, posameznik se lahko o njih pozanima pri svojem zdravniku oz. v zdravstvenem domu. V stiski lahko poišče strokovno pomoč tudi v eni od psiholoških svetovalnic na različnih lokacijah po Sloveniji. Med drugim so to:

- info@posvet.org (031 704 707; naročanje vsak delovnik med 12. in 19. uro);

- svetovalnica@nijz.si (031 778 772; naročanje vsak delovnik med 8. in 15. uro).

Za podatke o ustreznih oblikah pomoči ali samo za podporo in pogovor se lahko obrne tudi na telefone za pomoč v stiski:

- klic v duševni stiski: 0152099 oo (vsak dan med 19. in 7. uro zjutraj);

- zaupna telefona Samarijan in Sopotnik: 116123 (24 ur na dan, vsak dan), klic je brezplačen;

- Društvo sos telefon za ženske in otroke - žrtve nasilja: 080 1155 (pon.-pet. med 12. in 22. uro; sob., ned., prazn. med 18. in 22. uro), klic je brezplačen;

- TOM telefon za otroke in mladostnike: 116111 (vsak dan med 12. in 20. uro), klic je brezplačen.

Za podporo, pogovor in nasvet o ustreznih oblikah pomoči lahko uporabi tudi pomoč na spletu: 
- zdravstveni portal s svetovalnimi forumi za odrasle (družinska medicina, psihiatrija, obporodne stiske): http://www.med.over.net;

- spletna svetovalnica za mlade: www.tosemjaz.net;

- spletna postaja za razumevanje samomora Živ? Živ!: www.zivziv.si;

- spletna stran Društva DAM: www.nebojse.si.

\section{Zaključek}

Kompetenčni model omogoča usmerjeno izpopolnjevanje psihologov na področju javnega duševnega zdravja in še posebej samomorilnosti. Omogoča prepoznavo široke palete intervencij, ki so pomembne za to področje. Usmerjeno vseživljenjsko izpopolnjevanje, urjenje spretnosti in vključenost $\mathrm{v}$ supervizijo na področju delovanja $\mathrm{z}$ osebnimi stiskami in preprečevanja samomora je ključno tudi zato, ker zahteva veliko osebne energije psihologa oz. tistega, ki je v vlogi vratarja sistema. Vlaganje v tak sistem lahko dolgoročno ugodno vpliva tudi na indikatorje javnega duševnega zdravja.

\section{Literatura}

Hegerl, U., Mergl, R., Havers, I., Schmidtke, A., Lehfeld, H., Niklewski, G., in Althaus, D. (2009). Sustainable effects on suicidality were found for the Nuremberg alliance against depression. European Archives of Psychiatry and Clinical Neurosciences, 260(5), 401-406.

Mann, J. J., Apter, A., Bertolote, J., Beautrais, A., Currier, D., Haas, A., Hegerl, U., Lonnqvist, J., Malone, K., Marušič, A., Mehlum, L., Patton, G., Phillips, M., Rutz, W., Rihmer, Z., Schmidtke, A., Shaffer, D., Silverman, M., Takahashi, Y., Varnik, A., Wasserman, D., Yip, P., in Hendin, H. (2005). Suicide prevention strategies: A systematic review. JAMA: The Journal of the American Medical Association, 294(16), 2064-2074.

Neeleman, J., De Graaf, R., in Vollebergh, W. (2004). The suicidal process: Prospective comparison between early and later stages. Journal of Affective Disorders, 82(1), 43-52.

O'Carroll, P. W., Berman, A. L., Maris, R. W., Moscicki, E. K., Tanney, B. L., in Silverman, M. M. (1996). Beyond the Tower of Babel: A nomenclature for suicidology. Suicide and Life-Threatening Behaviour, 26(3), 237-252.

Retterstol, N. (1993). Suicide: A European perspective. Cambridge University Press.

Roškar, S., Podlesek, A., Zorko, M., Tavčar, R., Dernovšek, M. Z., Groleger, U., Mirjanič, M., Konec, N., Janet, E., in Marušič, A. (2010). Effects of training program on recognition and management of depression and suicide risk evaluation for Slovenian primary-care physicians: Followup study. Croatian Medical Journal, 51(3), 237-442. 
Rutz, W., Carlsson, P., von Knorring, L., in Wålinder, J. (1992). Cost-benefit analysis of an educational program for general practitioners by the Swedish Committee for the Prevention and Treatment of Depression. Acta Psychiatrica Scandinavica, 85(6), 457-464.

Van Heeringen, C. (2001). The suicidal process and related concepts. V C. van Heeringen (ur.), Understanding suicidal behaviour: The suicidal porcess approach to research, treatment and prevention (str. 3-15). Wiley.

Zalsman, G., Hawton, K., Wasserman, D., Heeringen, K., Arensman, E., Sarchiapone, M., Carli, V., Höschl, C., Barzilay, R., Balazs, J., Purebl, G., Kahn, J. P., Sáiz, P. A., Bursztein Lipsicas, C., Bobes, J., Cozman, D., Hegerl, U., in Zohar, J. (2016). Suicide prevention strategies revisited: 10year systematic review. The Lancet Psychiatry, 3(7). https://doi.org/10 $.1016 /$ S2215-0366(16)30030-X

\section{Identify and act on suicidal behavior}

Suicide is a huge social and public health problem. One of key approaches to suicide prevention is collaboration and education with gatekeepers and psychologists are among them. It's important that gatekeeprs have a feeling of competence and necessary knowledge to intervene in case of suicide risk. Among competencies that are of most importance to psychologists in case of suicide risk are: identification of suicide risk, how to pose a question on suicidal tendencies, perform a risk assesment and offering professional help. It's important that psychologists are informed about suicide warning signs as this enables on time identification of those at risk. In the phase of intervention it's of outmost importance that professionals are aware and accept the boundires of personal resposibility and do not get frightened once they've identified those feelings since this can obstruct intervention. Understanding the Question-Persuade-Reffer approach can be helpful when structuring intervention or risk management as well as collaboration with other professionals. Last but not least it's important that psychologists understant the bereavement process after suicide which among other includes also offering support. In this regard the Model of Growing flower can be helpful to understand the social context of mourning, especially when mourning after suicide of a belowed one (integration of events, rituals, expressing one's emotions in the family or broader environemnt). 